Article

\title{
Undergraduate Biology Students' Teleological and Essentialist Misconceptions
}

\author{
Florian Stern ${ }^{1}$, Kostas Kampourakis ${ }^{2, *}$, Catherine Huneault ${ }^{3}$, Patricia Silveira ${ }^{1}$ \\ and Andreas Müller 4 \\ 1 Faculty of Sciences, University of Geneva, 1211 Geneva, Switzerland; Florian.Stern@unige.ch (F.S.); \\ Patricia.Silveira@unige.ch (P.S.) \\ 2 Faculty of Sciences, Section of Biology and University Institute of Teacher Education (IUFE), \\ University of Geneva, 1211 Geneva, Switzerland \\ 3 Center for Teaching and Learning Support, University of Geneva, 1211 Geneva, Switzerland; \\ Catherine.Huneault@unige.ch \\ 4 Faculty of Sciences, Section of Physics and University Institute of Teacher Education (IUFE), \\ University of Geneva, 1211 Geneva, Switzerland; Andreas.Mueller@unige.ch \\ * Correspondence: Kostas.Kampourakis@unige.ch
}

Received: 13 July 2018; Accepted: 27 August 2018; Published: 31 August 2018

check for updates

\begin{abstract}
Research in developmental psychology has shown that deeply-rooted, intuitive ways of thinking, such as design teleology and psychological essentialism, impact children's scientific explanations about natural phenomena. Similarly, biology education researchers have found that students often hold inaccurate conceptions about natural phenomena, which often relate to these intuitions. In order to further investigate the relation between students' conceptions and intuitions, we conducted a study with 93 first year undergraduate students in biology. They were asked to express their level of agreement or disagreement with six misconception statements and to explain their choices in a two-tier test. Results showed a tendency for students to agree with teleological and essentialist misconceptions. However, no association was found between students' teleological and essentialist conceptions as expressed in their agreement or disagreement with the various misconception statements. Moreover, we found evidence of a variable consistency across students' answers depending on the misconception considered, which indicates that item features and contexts may have an effect on students' answers. All together, these findings provide evidence for considerable persistence of teleological and essentialist misconceptions among students. We suggest future directions for thinking, studying, and analyzing students' conceptions about biological phenomena.
\end{abstract}

Keywords: teleology; essentialism; misconceptions; preconceptions; intuitions; conceptual obstacles

\section{Introduction}

From our early childhood, we experientially formulate conceptions of the world which are described as preconceptions. As we grow up, we often assimilate knowledge which further modifies our preconceptions, occasionally turning them into more complex but incorrect conceptions which are described as misconceptions. The distinction between preconceptions and misconceptions is important because although people may restructure or reorganize their conceptions when they acquire new knowledge, this may be done in the wrong way. In other words, new knowledge (e.g., acquired at school) does not guarantee a correct understanding of concepts if the old conceptions are not properly restructured [1]. Therefore, we consider the term "preconceptions" to refer to students' conceptions about entities and phenomena in general, and the term "misconceptions" to refer to those 
preconceptions that are scientifically illegitimate or simply wrong [2]. What this distinction aims at pointing out is that not all preconceptions are wrong. Quite the contrary, it is generally agreed that preconceptions should not be viewed as evidence for the lack of abilities, but rather as a tool used by people to make sense of the world around them. In this sense, preconceptions are key elements to drive conceptual change in any field of science, because new knowledge should be built upon them [3].

Science education researchers have found that students often misunderstand basic biological concepts. In the case of genetics, for example, studies at various age levels have highlighted the poor understanding of biological inheritance among preschoolers of the relations and resemblances between parents and their offspring [4], the lack of consistency in explaining heredity across several tasks [5,6], or the difficulty in locating inheritance information in the cells of an organism [7]. More strikingly, it has been found that even biology teachers [8] may hold inaccurate conceptions such as genetic determinism, a conception implicitly advanced in the oversimplified presentations of gene action found in textbooks published in various countries [9]. These misunderstandings have various origins, which must be clearly identified in order to effectively address them during teaching [10].

Biology undergraduates are no exception. Recent research has focused on the difficulties encountered by novice students, and the differences in understanding biological concepts between them and experts in biology (we consider novice students all those who have not received any biology education at the university level, and we use the term experts for all those who have, or are about to get, a degree in biology. This category includes biology major students, biology teachers or biology professors, who are expected to have a better understanding of biological phenomena than novices.). For example, researchers have documented several misconceptions associated with various biological concepts, such as genetic drift [11], natural selection [12], matter-energy transformation [13] and cellular respiration and photosynthesis [14]. It seems that students hold several erroneous conceptions, and these should be considered as a starting point for guiding future research focusing on how the gap between students' and experts' knowledge might be reduced. Therefore, investigating the conceptions of first year undergraduates, that is, of students who have just finished high school, is very important in order to see what kind of conceptions they hold after completing secondary education.

But challenging these misconceptions requires understanding their origins. Conceptual development research suggests that students' conceptions are often influenced by deeply-rooted intuitions such as design teleology and psychological essentialism. Simply put, design teleology is the intuition that an intentional agent has designed a structure for a particular goal or function, whereas psychological essentialism is the intuition that organisms have underlying essences, which are fixed and thus unchangeable. These conceptions have been found to be important conceptual obstacles that impede students' understanding of evolution ([15-17]; see Section 2.1 and 2.2 below for a detailed discussion of design teleology and psychological essentialism). It is therefore possible that students' misconceptions are not only due to their misunderstanding of the respective topics, which might be addressed by further teaching on the topic. Rather, it could be the case that their misconceptions are also due to deeply held intuitions that preclude them from understanding the respective scientific concepts, despite further teaching. If this is the case, then teaching should also explicitly address these intuitive ways of thinking.

Recently, Coley and Tanner [18] considered three intuitive ways of thinking about the world: teleological, essentialist, and anthropocentric thinking. The association between these ways of thinking and twelve misconceptions, defined as scientifically inaccurate biological ideas, was investigated among 137 biology and non-biology major students. They found a strong agreement of students with misconception statements, as $93 \%$ of biology majors and $98 \%$ of non-biology majors agreed with at least one of those, whereas many of them also exhibited an explicit use of teleological, essentialist, or anthropocentric reasoning in their written justifications. In addition, a higher consistency between the agreement with misconception statements on the one hand and the presence of the respective intuitions in the written justifications on the other hand, was found among biology majors than non-biology majors. These results supported the conclusion that an important interaction exists between intuitive ways of thinking and biological misconceptions. In an attempt to extend this research, 
in this study we investigated whether there were any correlations between students' teleological and essentialist misconceptions. If no correlations were found, then the teleological and essentialist intuitions should be studied and addressed separately. However, if correlations were found then further research should clarify the nature and the strength of this correlation. To the best of our knowledge, the correlation of teleological and essentialist misconception has not been investigated in detail in previous studies, with the exception of Coley and Tanner [18] who concluded through a regression analysis that teleological and essentialist intuitions are not related.

Similarly to Coley and Tanner [18], in the present study we investigated biology undergraduate students' level of agreement with misconception statements, the prevalence of teleological and essentialist explanations in their justifications, as well as the presence or absence of a relation between them. Furthermore, we have decided to only consider teleological and essentialist thinking, but not anthropocentric thinking defined by Coley and Tanner [19] as "the tendency to reason about unfamiliar biological species or processes by analogy to humans". First of all, this is not the definition of anthropocentrism but of anthropomorphism. Anthropocentrism means that humans are in the center of something and that whatever we are talking about has humans in its center, whereas anthropomorphism means that we apply human properties to non-human entities. We consider anthropomorphism as based on intentionality, which in turn could be considered as a special case of teleological thinking (see also [20]), therefore we have decided not to consider it separately in this study.

Our study is, in some sense, a replication of Coley \& Tanner [18], however, it exhibits novel elements as well. One novelty of our study consists in having been conducted in a different (non-US) population and in a different language (French). Replication studies are really necessary, but more often than not they are not conducted. Reaching the same conclusions with Coley \& Tanner [18] would be very important, as we would corroborate their findings. We also propose a particular way of analyzing and representing our findings that might of interest and useful to future studies in this field.

The main aim of the present study is therefore to study first year undergraduate students' misconceptions related to biology. Our goal is to explore which misconceptions are still held by students after completing their secondary education. We believe that figuring out which misconceptions persist after secondary biology teaching might provide the grounds for revising secondary biology curricula in order to challenge these misconceptions more efficiently.

\section{Theoretical Background: Teleology and Essentialism}

\subsection{Teleological Thinking in Biology}

Answering a "why" question with an "in order to" statement can be described as a teleological explanation, because it is based on a goal or role. Such explanations are popular among both children and adults, as they are useful for describing, explaining, and understanding what is going on in our daily life and in the world around us. For example, if one is asked "Why do you buy a hat?", a typical answer would be "I buy a hat in order to be protected from the sunlight". This is a teleological statement, in which an intentional agent acts in order to fulfill a particular goal. In this case, the goal is clear as it is directly related to the intention of the person. Similarly, if we asked "Why do airplanes have wings?", the answer would also be simple and straightforward: "In order to fly". Airplanes are artifacts that have been intentionally and intelligently designed by humans to have the appropriate wings in order to fly.

But if we asked "Why do birds have wings?", could the response simply be "In order to fly"? This is a more complicated case than the previous one. Wings are certainly used by many birds in order to fly, but not by all; think, for example, of penguins and ostriches. But even for those birds who use their wings to fly, there is no intention behind this fact. Whereas airplanes have been intentionally and intelligently designed by humans to have wings in order to fly, bird wings have evolved through a historical, natural process. Birds fly because they have wings; wings may 
have provided an advantage in the survival and reproduction of their ancestors and so there has been selection for them, in the sense that this feature has provided an advantage in the survival and reproduction of their bearers and thus became prevalent in the respective population across generations. Therefore, we can distinguish between two different kinds of teleology: a design teleology in the case of airplanes, in which an intentional agent designed a structure for a particular goal or function; and a selective teleology in the case of birds in which natural selection has unintentionally brought about a structure that performs a particular function that in turn confers to its bearers an advantage because of which this particular structure exists [17,21] (Distinguishing between these two kinds of teleology in students' responses may be very challenging. Indeed, a single teleological statement is generally not sufficient to grasp one's way of thinking, as it can either be a way of speaking used for a teleology based on selection, or refer to design-teleology.).

Several studies have shown that design-teleological thinking is an impediment in the case of understanding the theory of evolution, especially natural selection, with misconceptions being persistent among children and adults $[15,17]$. Several studies have shown the strong tendency of children to intuitively use teleological explanations for organisms and artifacts; however, it is not entirely clear whether children always use them for non-living natural objects as well [22-24]. Other research has suggested a possible developmental shift from an indiscriminate to a more discriminate teleology [25]. Children also seem to have a stronger preference for teleological explanations than adults or experts, exhibiting a purpose-based view of inheritance whereby animals can acquire properties that serve a purpose in the environment in which they live [26]. Interestingly, not only children, but also physical scientists seem to use teleological explanations to make sense of the natural phenomena [27]. Some studies have suggested that the teleological bias may be independent of cultures: non-schooled Romani adults have been found to use teleological reasoning about natural phenomena [28], and Chinese people were also found to provide purpose-based explanations [29].

Teleological reasoning can be used for explanations at different levels: molecular, genetic, evolutionary, cellular, organismal, ecological. Some examples of teleological misconception statements from Coley and Tanner ([19], see p. 210) are as follows:

- Genes turn on so that the cell can develop properly;

- Birds have wings so they can fly;

- Plants give off oxygen, because animals need oxygen to survive;

- Individual organisms adapt and change to fit their environments;

- Evolution is the striving toward higher forms of life on earth.

These are easily recognizable as teleological statements because they contain specific words such as "so (that)", "need", "to", "towards". They implicitly assume a particular goal in a biological process. In this case, it is accurate to think that a feature exists for a role because it has been favored by natural selection for fulfilling this role, and that this role exists because of what it does; this is a robust form of natural (selective) teleology. However, this is not what students usually have in mind. In contrast, they intuitively think in terms of design. Overall, the problem is that a confusion emerges from thinking of organisms as artifacts, and especially of thinking about the parts of organisms in the same way with the parts of artifacts. In this case, design teleological thinking can be a serious and persistent conceptual obstacle that must be explicitly addressed in order to achieve a correct understanding of biological processes ([17], Chapter 3). In the present study, however, we describe students' responses as teleological when they contain the specific words mentioned above, without distinguishing between design and selective teleology. The reason for this is that just a distinction was not possible through their short justifications. 


\subsection{Essentialist Thinking in Biology}

Essentialism is the idea that entities have essences, that is, a set of properties that all members of the kind must have, and the combination of which only members of the kind do, in fact, have [30]. A special kind of essentialism is psychological essentialism, the intuition that organisms have underlying essences, which are fixed and thus unchangeable [31]. The characteristics of organisms are the outcome of development on the basis of a particular genetic material expressed under particular environmental conditions. Therefore, the essences of organisms could be their potential to develop certain features that are specific to their kind, but at the same time also exhibit plasticity that contributes to individual variation among the members of the same kind [32]. However, the essences of organisms are not fixed because, due to developmental plasticity, the organisms of the same species can be very different from one another, and different populations may eventually evolve to distinct species ([33], see pp. $4-5,8)$.

Artifacts are objects designed and created by humans in order to fulfill an intended use, which is reflected in their features. An airplane has wings in order to fly, and wings are essential features of an airplane because they are designed to serve the purpose of flying. This is why an AirBus and a Cessna have wings of different sizes, which are in each case of the appropriate size for flying. Even if an airplane is not used for flying, and is instead put to a museum, its essence does not change because it was designed for flying and it still has the appropriate features for this purpose, even if it is not anymore used for that $[17,34]$. Therefore, the essence of an artifact is determined by its intended use. This why the essences of artifacts are fixed. Even if an artifact is slightly modified through time, for example if a table is a bit damaged due to a frequent use, it will still be used as a table despite the small damages. Consequently, the role it fulfills will remain the same, and so will be its essence. As a result, the essences of organisms differ significantly from the essences of artifacts (The only case where the essence of an artifact could change is when it is intentionally modified in an irreversible way in order to fulfill a new role, e.g., cutting out the upper part of a chair and leaving what resembles a small table).

Essentialist thinking is widespread among children and adults who tend to quickly conceive of essences, which they often perceive as fixed. Such a way of thinking is useful for making sense of what we see in the world around us, but can also generate inaccurate conceptions. Children seem to believe that organisms are characterized by underlying, distinctive "essences" that make them what they are. For instance, children consider internal, invisible features and properties as more important than external ones [35]. Essentialist thinking is about considering members of a category as similar with respect to shared properties [36], and likely to develop similar new features [4,35]. Not only children but also adults tend to provide essentialist explanations; preschool children and adults from a variety of cultural contexts expect members of a category to be alike in non-obvious ways [37]. Interestingly, it seems that children tend to believe that the essences of organisms are more fixed than those of artifacts. As a result, studies investigating the influence of essentialism on understanding biological concepts have shown that essentialist thinking is a conceptual obstacle to understanding evolution [16,17].

Essentialist reasoning can be used at different biological levels: molecular, cellular, organismal, ecological. Some examples of misconception statements hypothesized as essentialist from Coley and Tanner ([19], see p. 211) are as follows:

- Homeostasis keeps the body static and unchanging;

- Members of the same species are almost identical in their physical characteristics;

- If left alone, a wetland ecosystem will remain a wetland indefinitely;

- Because different cells in an organism have different physical characteristics, they must contain different DNA;

- Changing a single gene in an organism results in a new kind of organism. 
These are psychological essentialist statements because they contain specific terms such as "static", "unchanging", "identical", "indefinitely", which implicitly assume a fixed category associated with a biological process.

In sum, similarly to designed-based teleological thinking, psychological essentialist thinking is legitimate for artifacts whose essences remain fixed, but does not hold for organisms that can undergo major changes during development and evolution. Again, the misunderstanding often stems from thinking of organisms as artifacts, in which case psychological essentialist thinking can be a serious and persistent conceptual obstacle to address for a correct understanding of biological concepts. In the present study we have focused on stability and fixity as indications of essentialist reasoning.

\subsection{Research Questions}

As conceptual development research suggests, these two intention-based intuitions (design teleology and psychological essentialism) arise early in childhood. Thus, it is necessary not only to challenge students' conceptions about biological phenomena, but also their essentialist and teleological intuitions on which these conceptions may be based. It is therefore interesting to look in more detail at students' teleological and essentialist conceptions. We thus conducted a study in order to provide answers to the following research questions:

1. What level of agreement with teleological and essentialist misconception statements do 1st year undergraduate biology students exhibit?

2. Are 1st year undergraduate biology students consistent in their responses within the various items? That is, are they consistent in their agreement or disagreement with each misconception statement and the respective justification?

3. Are 1st year undergraduate biology students consistent in their responses between the various items of the same type? That is, are their responses either to the three teleological or to the three essentialist statements consistent with one another?

4. Is there a correlation between 1st year undergraduate biology students' teleological and essentialist conceptions as documented by their responses to the items of this study?

Our first goal was to investigate whether misconceptions would be prevalent among the students who participated in our study (research question 1). These students had just enrolled in university studies, and so we anticipated that this research would likely provide us with a useful overview of the misconceptions they held after having finished secondary school. In addition, we wanted to explore whether students would be consistent within items, that is whether they would exhibit the same conception between their responses in the closed and the open part of the same item (research question 2). This is why we explicitly asked them to justify their agreement or disagreement with the misconception statements. In contrast, given previous research that has shown that the context of the questions has an impact on students' teleological responses (e.g., [38,39]), we wanted to see whether students would be inconsistent across items, that is whether students would not agree with all teleological or all essentialist misconception statements, but only with some of them (research question 3). Finally, to the best of our knowledge, and despite the numerous studies that have been conducted on students' teleological and essentialist conceptions, Coley and Tanner [18] is the only study that has investigated the correlation between teleological and essentialist conceptions. We therefore wanted to investigate whether there would be any correlation between students' teleological and essentialist conceptions (research question 4).

Let us elaborate a bit as to why this last point is important. Whereas teleology and essentialism are conceptually distinct, as explained above they both have a relation to intentionality. In the case of design teleology, something exists for a purpose because an agent had the intention to fulfil this purpose. For instance, airplanes have wings because humans produced them by implementing a particular design because they had the intention to fly. At the same time, the intended use of airplanes, flight, can be considered as their essence. Wings are thus directly related to the essence of airplanes that 
in turn reflects the intention of an agent to serve a purpose. Therefore, in both cases, the idea that airplanes have wings in order to fly and the idea these wings are fixed because they relate to the essence of airplanes are both related to a common underlying idea of intentionality and intended use. This common relation to intentionality and intended use is why it is possible for teleological and essentialist conceptions to be correlated.

\section{Methods}

\subsection{Misconception Statements}

For the present study, we focused on misconceptions, which we consider as students' ideas that are wrong or incompatible with scientific knowledge. We thus selected six misconception statements, three of which are associated with teleological thinking (teleological statements), whereas the other three are associated with essentialist thinking (essentialist statements). As explained in the sections above, these are fundamental misconception that hinder students' understanding of biological science. The six considered misconception statements were inspired by the Coley and Tanner study [18], and are described in Table 1 below. We have selected the particular misconception statements because we considered them as covering the usual types of teleological and essentialist misconceptions that first year undergraduates (who have just finished secondary school) would hold. Where necessary, appropriate and slight modifications were made from the wording used by Coley and Tanner [18], in order to ensure their comprehensibility by our participants.

These items were translated and back-translated from English to French, as the study involved French-speaking students. To our knowledge, the misconception statements used in the Coley and Tanner study [18] have only been used with English-speaking students. Therefore, in our study we aim at investigating whether the results of the Coley and Tanner study [18] could be replicated with a French-speaking, undergraduate student population. We anticipated that the similarities and differences that we might identify between the English-speaking students of the original study and the French-speaking students of our study could have important implications for the validity of these statements as a research tool, as well as for the robustness of the relationship between the respective misconceptions and intuitive reasoning. The statements in French, exactly as given to the students in our study, are presented in Appendix A, and an English translation is given in Appendix B.

Table 1. Misconception statements used in the present study.

\begin{tabular}{cccc}
\hline Teleology & Short Description & Essentialism & Short Description \\
\hline $\begin{array}{c}\mathrm{S}_{1} \text { Plants produce } \\
\text { oxygen so that animals } \\
\text { can breathe. }\end{array}$ & Oxygen for animals & $\begin{array}{c}\mathrm{S}_{2} \text { Aside from } \\
\text { differences of sex or age, } \\
\text { members of a same } \\
\text { species are identical. }\end{array}$ & Identical members \\
\hline $\begin{array}{c}\mathrm{S}_{3} \text { Animals develop } \\
\text { protective "camouflage" } \\
\text { in order to avoid } \\
\text { their predators. }\end{array}$ & $\begin{array}{c}\text { Camouflage } \\
\text { for predators }\end{array}$ & $\begin{array}{c}\mathrm{S}_{4} \text { Species can change } \\
\text { during evolution, but } \\
\text { some characteristics } \\
\text { always remain the same. }\end{array}$ & Stable characteristics \\
\hline $\begin{array}{c}\mathrm{S}_{5} \text { Organisms have genes } \\
\text { for producing all the } \\
\text { molecules they need. }\end{array}$ & Genes for all molecules & $\begin{array}{c}\mathrm{S}_{6} \text { Without external } \\
\text { influences, an ecological } \\
\text { community will remain } \\
\text { stable indefinitely. }\end{array}$ & ecological community \\
\hline
\end{tabular}

It should be noted that misconception statements $S_{1}, S_{3}$, and $S_{5}$ are characterized by the use of typical goal-related words such as "in order to" or "for", which are assumed to indicate teleological thinking. Also, misconception statements $\mathrm{S}_{2}, \mathrm{~S}_{4}$, and $\mathrm{S}_{6}$ are characterized by the use of typical essence-related words such as "identical" or "remain" that are assumed to indicate essentialist thinking. In this study, we did not only ask students whether or not they agreed with misconception statements $S_{1}-S_{6}$, but we also asked them to justify their choices, that is, explain why 
they agreed or disagreed with each of the statements. Thus, we could analyze the consistency of students' responses both between items of the same type $\left(\mathrm{S}_{1}, \mathrm{~S}_{3}\right.$ and $\mathrm{S}_{5} ; \mathrm{S}_{2}, \mathrm{~S}_{4}$ and $\left.\mathrm{S}_{6}\right)$, and within each item, that is, by considering whether the choice made and the justification given were consistent or not.

\subsection{Participants}

A total of 93 first year undergraduate biology students from the University of Geneva, participated in the study on the very first day of the academic year. Each participant was given the questionnaire and was asked to complete it individually within $40 \mathrm{~min}$. Two of the authors explained the aims of the study to students, who were encouraged but not in any way forced, to participate. It was explained to them that the questionnaire had nothing to do with their course grades, and that it was necessary for research and evaluation purposes. It was also noted that their responses would be anonymous (a code was generated by students in order to be able to distinguish among them) and that all data would be treated in a confidential manner. Participants came from a variety of backgrounds and educational systems. In order to refrain from breaching confidentiality or make them feel uncomfortable we did not collect any personal data such as ethnic background, type of secondary school attended before the university, educational level of parents, and so on.

\subsection{Research Instrument}

The questionnaire used was based on the one used in the Coley and Tanner study [18]. Each question consisted of the following:

(1) A closed part that included one of the six misconception statements in Table 1, for each of which students were asked to express their degree of agreement or disagreement on a 5-level scale ("completely disagree"; "rather disagree"; "I do not know"; "rather agree"; "completely agree");

(2) An open part in which they were asked to justify their choice in the first part of each item. In this case, students had adequate space (a few lines) to describe their thinking.

Such tests are described as two tier-tests, and are a useful tool for assessing students' knowledge [40]. We used a questionnaire with this structure because we intended to look at two types of consistency in students' responses: Consistency Within an item (CW) and Consistency Between items (CB). CW is about whether or not students' choices in the closed part of each item and their written justification in the open part of the same item expressed the same conception (e.g., if they had chosen to agree with a misconception statement, did their justification exhibit components of that misconception?). CB is about whether or not students exhibited the same conceptions in those items referring to the same misconception (e.g., did students answers across either the closed or the open parts of items $S_{1}, S_{3}, S_{5}$ or items $S_{2}, S_{4}$, and $S_{6}$ indicate that they held the same type of conception?).

\subsection{Analysis}

First, related to the first research question, that is, the level of agreement with teleological and essentialist misconception statements that first year undergraduate biology students exhibit, we analyzed the level of students' agreement with each of the six misconception statements $S_{1}-S_{6}$, using the statistical software R [41]. At the level of individual statements, we calculated the frequencies of the various answers ("completely disagree", "rather disagree", "I do not know", "rather agree", and "completely agree") for each statement. This aimed at highlighting how strongly each misconception statement was being rejected or endorsed by the participants in this study, and particularly which were the differences in rejection and endorsement rates among the various misconception statements.

Related to our second research question, that is whether first year undergraduate biology students were consistent in their agreement or disagreement with each misconception statement and the respective justification that they gave, we analyzed the $\mathrm{CW}$ for each item. We examined students' agreement as a categorical binary variable for the closed parts on one side and for the open parts on 
the other side. Based on students' choices in the closed parts, all "completely disagree" and "rather disagree" and "I do not know" responses were included in a general "absence of the misconception" category, whereas the "rather agree" and "completely agree" responses were included in a general "presence of the misconception" category." Regarding the open parts of the items, we coded students' responses as exhibiting the "presence of the (teleological/essentialist) intuition" when we interpreted a participant's written justification as exhibiting the respective kind of thinking; we also coded students' responses as exhibiting an "absence of the intuition" when we interpreted a participant's written justification either as not exhibiting the respective kind of thinking, or as explicitly rejecting that kind of thinking or when it was impossible to attribute the response in any of the previous categories. Students' justifications in the open parts were coded independently by two researchers, reaching an initial agreement level of $91 \%$. The remaining responses were discussed until absolute agreement was reached about how they should be coded.

As data were dichotomous, both phi coefficient and Pearson's Chi-square test were computed for assessing any relationship within the closed and the open part of each statement (significance level at $p<0.05$ ). The phi coefficient, defined as $\varphi=\sqrt{\frac{\chi^{2}}{n}}$ where $\chi^{2}$ is the observed value of the Pearson's Chi-square test and $n$ the total number of observations, measures the strength of relationship between two dichotomous variables, while Pearson's Chi-square test indicates whether the relationship is statistically significant or not [41].

Table 2 presents some examples of students' responses for each category. We should note that in the coding we did not distinguish between the (scientifically legitimate) selective teleology and the (scientifically illegitimate) design teleology, as the short length of students' responses did not allow for such a distinction to be made. For the same reasons, we did not analyze in detail what students could perceive as the essences of organisms (their genes? their developmental potential?). Therefore, in our results we describe students' conceptions as teleological or essentialist without distinguishing between legitimate or illegitimate types of teleology and essentialism.

Table 2. Examples of students' responses for each category.

\begin{tabular}{|c|c|c|c|c|}
\hline & Codes & Example 1 & Example 2 & Example 3 \\
\hline \multirow{3}{*}{ Teleology } & $\begin{array}{l}\text { Presence of } \\
\text { the intuition }\end{array}$ & $\begin{array}{c}\text { I think that plants produce } \\
\text { oxygen for their own } \\
\text { survival, oxygen is also } \\
\text { allowing animals to live, } \\
\text { this is the beauty of } \\
\text { the nature. } \\
\text { [S } \mathrm{S}_{1} \text { : Oxygen for animals] }\end{array}$ & $\begin{array}{l}\text { I think that concealment } \\
\text { for protection has been } \\
\text { developed in order to } \\
\text { avoid predators. } \\
\text { [S } \mathrm{S}_{3} \text { : Camouflage } \\
\text { for predators] }\end{array}$ & $\begin{array}{l}\text { Genes have the goal to } \\
\text { produce all kind of proteins. } \\
\text { But it is not the organisms } \\
\text { who have chosen this } \\
\text { storage solution of } \\
\text { information which is DNA. } \\
\text { The environment has } \\
\text { allowed primitive organisms } \\
\text { to use DNA because this } \\
\text { was the most advantageous } \\
\text { for their existence. } \\
{\left[\mathrm{S}_{5} \text { : Genes for all molecules] }\right.}\end{array}$ \\
\hline & $\begin{array}{l}\text { Absence of } \\
\text { the intuition }\end{array}$ & $\begin{array}{l}\text { Plants do not produce } \\
\text { oxygen for this reason, } \\
\text { but the oxygen they } \\
\text { produce is the result of } \\
\text { their process } \\
\text { of photosynthesis. } \\
\text { Thus, oxygen is } \\
\text { a waste-product of } \\
\text { this process. } \\
{\left[\mathrm{S}_{1} \text { : Oxygen for animals] }\right.}\end{array}$ & $\begin{array}{l}\text { It is true that some animals } \\
\text { have developed methods } \\
\text { of concealment methods } \\
\text { that allow them to escape } \\
\text { their predators, but there } \\
\text { is no will to develop } \\
\text { this concealment. It is the } \\
\text { outcome of evolution by } \\
\text { natural selection. } \\
{\left[\mathrm{S}_{3} \text { : Camouflage }\right.} \\
\text { for predators] }\end{array}$ & $\begin{array}{l}\text { The genetic code of our } \\
\text { DNA gives a message to } \\
\text { RNA messenger which } \\
\text { codes proteins and } \\
\text { molecules needed by } \\
\text { our body. } \\
\text { [S } \mathrm{S}_{5} \text { : Genes for all molecules] }\end{array}$ \\
\hline & Unclear & $\begin{array}{l}\text { Plants take part in the } \\
\text { process of photosynthesis, } \\
\text { which produces oxygen. } \\
{\left[\mathrm{S}_{1} \text { : Oxygen for animals] }\right.}\end{array}$ & $\begin{array}{c}\text { Some animals develop } \\
\text { camouflage, adapt to their } \\
\text { environment and } \\
\text { to predators. } \\
{\left[\mathrm{S}_{3} \text { : Camouflage }\right.} \\
\text { for predators] }\end{array}$ & $\begin{array}{l}\text { Genes code for proteins. } \\
{\left[\mathrm{S}_{5}: \text { Genes for all molecules] }\right.}\end{array}$ \\
\hline
\end{tabular}


Table 2. Cont.

\begin{tabular}{|c|c|c|c|c|}
\hline & Codes & Example 1 & Example 2 & Example 3 \\
\hline \multirow{3}{*}{ Essentialism } & $\begin{array}{l}\text { Presence of } \\
\text { the intuition }\end{array}$ & $\begin{array}{l}\text { Indeed, only the } \\
\text { appearance changes but } \\
\text { the members of a same } \\
\text { species are identical. } \\
\text { [S } \mathrm{S}_{2} \text { : Identical members] }\end{array}$ & $\begin{array}{l}\text { Members of a species have } \\
\text { identical genes which do } \\
\text { not undergo changes } \\
\text { (essential genes). } \\
{\left[\mathrm{S}_{4} \text { : Stable characteristics] }\right.}\end{array}$ & $\begin{array}{c}\text { If there exists no abiotic } \\
\text { factors or biotic factors } \\
\text { which are modified, } \\
\text { the community will remain } \\
\text { indefinitely stable. } \\
\text { [S }{ }_{6} \text { : Stable } \\
\text { ecological community] }\end{array}$ \\
\hline & $\begin{array}{l}\text { Absence of } \\
\text { the intuition }\end{array}$ & $\begin{array}{l}\text { All the members of } \\
\text { a species are very similar } \\
\text { but not completely } \\
\text { identical because we all } \\
\text { have a different } \\
\text { genetic heritage. } \\
\text { [S } \mathrm{S}_{2} \text { : Identical members] }\end{array}$ & $\begin{array}{l}\text { Even though at first sight } \\
\text { some characteristics seem } \\
\text { to remain the same, } \\
\text { species do not stop to } \\
\text { evolve because they are } \\
\text { constantly selected by } \\
\text { environment, predators, } \\
\text { sexual selection and also } \\
\text { by sudden climate changes. } \\
\text { [S } \mathrm{S}_{4} \text { : Stable characteristics] }\end{array}$ & $\begin{array}{c}\text { If changes do not occur } \\
\text { inside the community, } \\
\text { for example mutations may } \\
\text { favor or disadvantage } \\
\text { a group of individuals. } \\
\text { [S } \mathrm{S}_{6} \text { : Stable } \\
\text { ecological community] }\end{array}$ \\
\hline & Unclear & $\begin{array}{l}\text { Several external factors } \\
\text { may exist, that can modify } \\
\text { the appearance in the } \\
\text { same species. For example, } \\
\text { the color of the skin } \\
\text { of mankind. Different dog } \\
\text { races belong all to the } \\
\text { same species. } \\
\text { [S }{ }_{2} \text { : Identical members] }\end{array}$ & $\begin{array}{c}\text { Species evolve with time } \\
\text { and sometimes over a long } \\
\text { period of time. They adapt } \\
\text { to their environment and } \\
\text { evolutions make it } \\
\text { possible to better survive } \\
\text { within a place. } \\
\text { [S } \mathrm{S}_{4} \text { : Stable characteristics] }\end{array}$ & 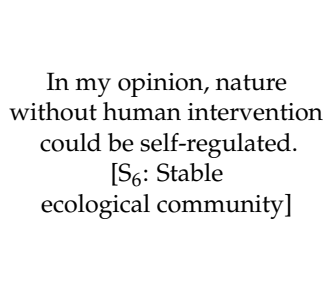 \\
\hline
\end{tabular}

Third, we investigated the consistency between (CB) the teleological statements on one hand, and the essentialist statements on the other hand. For both kinds of statements, we investigated the $\mathrm{CB}$ across closed parts and across open parts. We used the same two-level coding used for the analysis of CW, namely "presences of the (teleological/essentialist) intuition" or "absence of the (teleological/essentialist) intuition" as described above (significance level of Pearson's Chi-Square test $p<0.05)$. This analysis addresses our third research question, that is whether first year undergraduate biology students were consistent in their responses either to the three teleological or the three essentialist statements.

Finally, we investigated the possible correlation between teleological and essentialist conceptions. In particular, the three teleological statements were considered together and the three essentialist statements were also considered together. We considered a participant's level of agreement with teleological and essentialist statements as an ordinal scale. For each misconception, we adopted the following grading: 1 point for a complete agreement, 2 points for a partial agreement, 3 points for a partial disagreement, 4 points for a complete disagreement, so that each student had a score between 1 and 4 for each statement. All "I don't know" answers were removed, and therefore only 76 students (who responded to all six statements by either agreeing or disagreeing) were considered. Summing up scores on one hand for all three teleological statements, and on the other hand for all three essentialist statements, each student has a score between 3 and 12 for teleological reasoning and a similar one for essentialist reasoning. Therefore, a low score, such as 3 , would indicate a high agreement with the misconception statements, whereas a high score such as 12 would indicate a high disagreement with the misconception statements. In other words, the higher a student's score was, the higher a student's tendency to disagree with misconceptions was.

Pearson correlation test was also performed (significance level $p<0.050$ ). The plotting of essentialist versus teleological reasoning based on these scores provides a useful explorative insight for investigating the relation between these two intuitions. To extend the correlation analysis further, we investigated the statistical relations between the agreement with misconception statements and the frequency of the inferred intuitions from the open part through multiple regression analyses. We used the frequency of each intuition (teleological, essentialist) across all justifications as a predictor variable and conducted two different regression analyses, for which the average agreement with each type of 
misconception statement was considered as the outcome variable. We conducted these analyses for all 93 students.

\section{Results}

In our study, each student expressed and explained his/her agreement or disagreement with six misconception statements, three of which were associated with teleological thinking $\left(\mathrm{S}_{1}, \mathrm{~S}_{3}\right.$ and $\left.S_{5}\right)$, whereas the other three were associated with essentialist thinking $\left(S_{2}, S_{4}\right.$ and $\left.S_{6}\right)$. In the presentation of the results on students' responses to the closed part we have merged together students' responses that expressed partial or total agreement (dubbed as "agreement") and those that expressed partial or total disagreement (dubbed as "disagreement") with a misconception statement. The latter category also includes the "I don't know" responses. Regarding students' responses to the open part, for simplification and because we are mostly interested in the presence or the absence of the misconception, the descriptor "absence of the misconception" was used when students explicitly rejected teleological or essentialist statements, when they provided mostly descriptive explanations, as well as when their responses were unclear; accordingly, the phrase "presence of the misconception" was used when students' answers included explicit teleological or essentialist statements.

\subsection{Prevalence of Misconceptions among Students}

Overall, $97 \%$ of participants agreed with at least one misconception statement, and $49 \%$ of students agreed with at least three misconception statements. These findings indicate that these students had finished high school holding fundamental misconceptions, which in our view should be explicitly addressed in their introductory biology classes.

\subsubsection{Students' Responses to the Closed Parts of Items}

The misconception statements related to the same intuition each referred to a different context in order to see whether students would apply the same reasoning in all teleology or in all essentialism items. However, we found different levels of agreement for each item. Figure 1 indicates that in general students' agreement varied widely from one statement to another, ranging from a $75 \%$ complete or partial agreement with statement $\mathrm{S}_{4}$, "Species can change during evolution but some characteristics always remain the same", to a $12 \%$ complete or partial agreement with statement $S_{2}$, "Aside from differences caused by age and gender, members of the same species are identical". Overall, two statements $\left(\mathrm{S}_{3}\right.$ and $\left.\mathrm{S}_{4}\right)$ were endorsed by more than half of the students. As shown in Figure 1, the level of complete or partial agreement with teleological statements was $37 \%$ and $32 \%$ for statements $S_{1}$ and $S_{5}$, respectively, whereas it reached $60 \%$ for statement $S_{3}$. The level of complete or partial agreement with essentialist statements was $12 \%$ for statement $S_{2}$, about $28 \%$ for statement $S_{6}$, and $75 \%$ for statement $S_{4}$. Overall, there is a marked heterogeneity in students' level of agreement with the different misconception statements. 


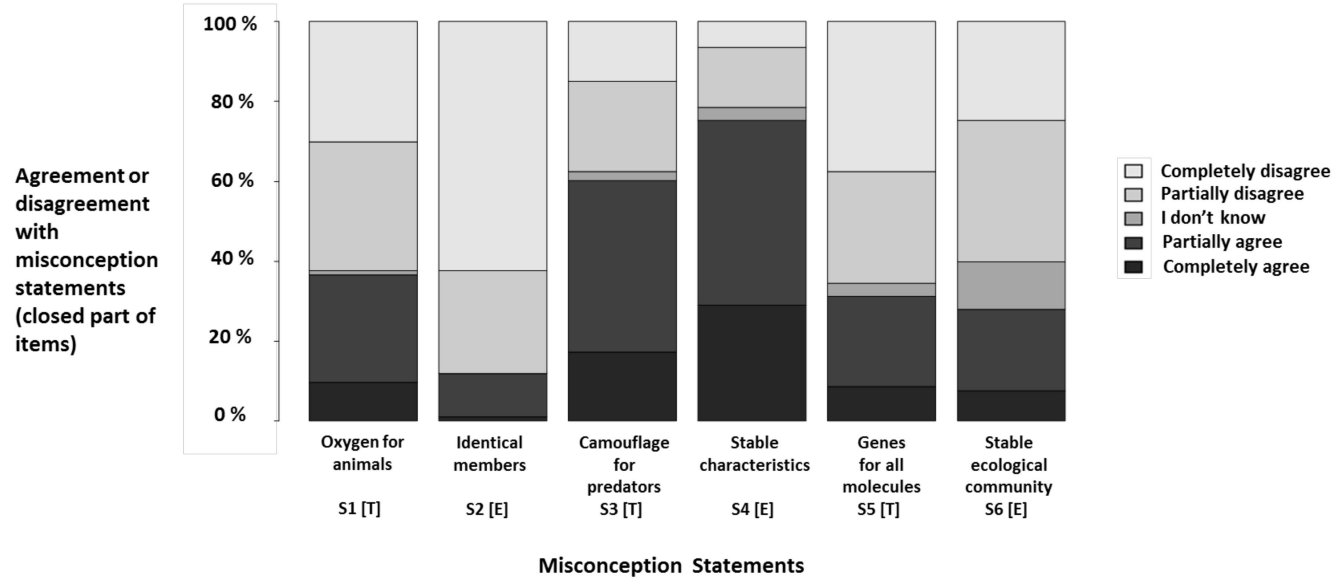

Figure 1. Students' agreement with each of the six misconception statements (closed parts of items), ranging from complete disagreement (black) to complete agreement (light grey).

\subsubsection{Students' Responses to the Open Parts of Items}

Teleological thinking was quite prevalent in students' responses as it was found in $37 \%$ of the written justifications for the misconception statements $\mathrm{S}_{1}$ "Oxygen for animals", and in $55 \%$ of the written justifications for the statement $\mathrm{S}_{3}$ "Camouflage for predators". In contrast, only $12 \%$ of students provided a teleological justification for statement $\mathrm{S}_{5}$ "Genes for all molecules". The prevalence of essentialist intuitions in students' answers was rather low for two statements as only $5 \%$ and $17 \%$ of them exhibited essentialist thinking in their justifications for items $\mathrm{S}_{2}$ "Identical members" and $\mathrm{S}_{6}$ "Stable ecological community", respectively. In contrast, 51\% of the students exhibited this intuition in their justifications for misconception statement $S_{4}$ "Stable characteristics" (Figure 2).

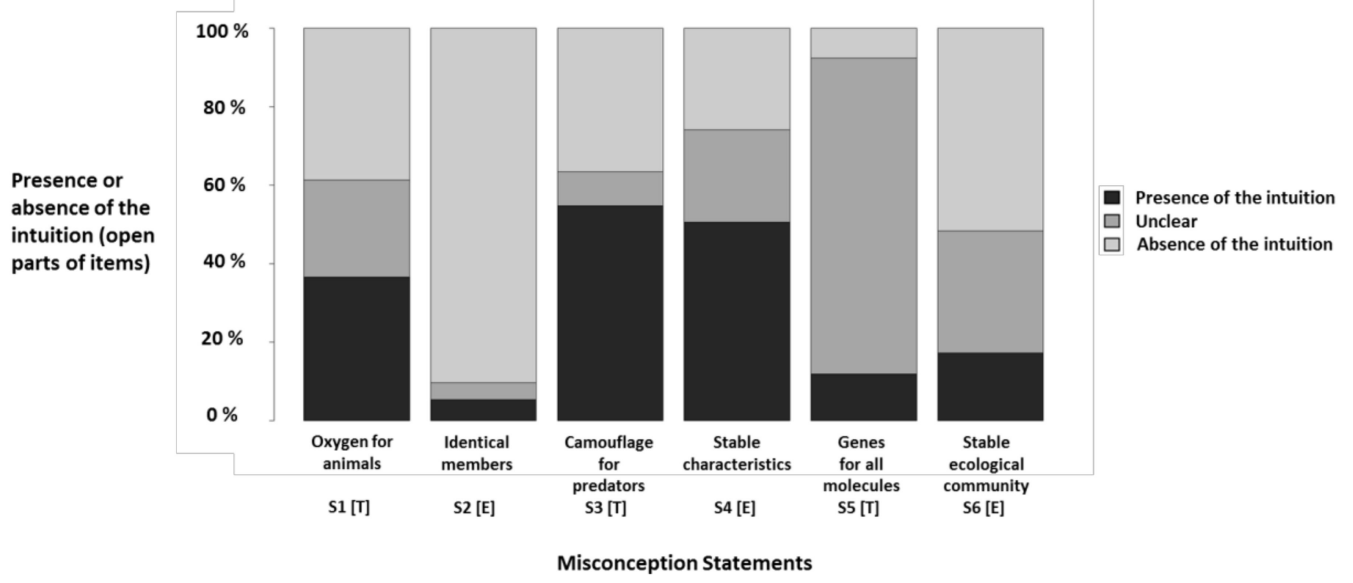

Figure 2. Students who exhibited the presence (black) or the absence of teleological or essentialist intuitions, or an unclear justification (gray), in responses to the open parts of the six misconception statements.

With respect to our first research question, that is, about the level of agreement with teleological and essentialist misconception statements, the conclusion is therefore that students exhibited different levels of agreement with the various misconception statements.

This was evident both in the choices they made in the closed parts of the items and in their written responses to the respective open parts of the items.

We should note at this point some issues related to the coding of students' responses to the open parts of the items. First, there was a high amount of responses to statement $\mathrm{S}_{5}$ "Genes for all 
molecules" (75\%) that were coded as "unclear", exactly because we could not code them as teleological or not. One reason for this may be the way the statement was formulated. Second, missing data, which represented less than $2 \%$ of the total data, were coded either as "I do not know" in the closed part or as "unclear" in the open part.

\subsection{Students' Consistency within Items}

Given that students expressed their agreement or disagreement with misconception statements (Section 4.1.1) and also provided justifications for these (Section 4.1.2), we considered it interesting to look at whether each student accepted or rejected a misconception statement in the closed part and simultaneously provided a consistent justification in the open part of each item, in response to our second research question, that is, whether first year undergraduate biology students were consistent in their agreement or disagreement with each misconception statement and the respective justification that they gave. Thus, we considered consistency within (CW) an item as a measure of the relationship between, for example, the agreement with a teleological misconception statement in the closed part and the use of teleological language in the open part (or vice versa). Given that students' justifications in the open parts of the items were explicitly related to their choices in the closed parts of the items, we generally expected students to be consistent within items. Figure $3 a, b$ show how many students agreed or disagreed with each of the six misconception statements and also expressed the respective intuition in the open part of the respective item.

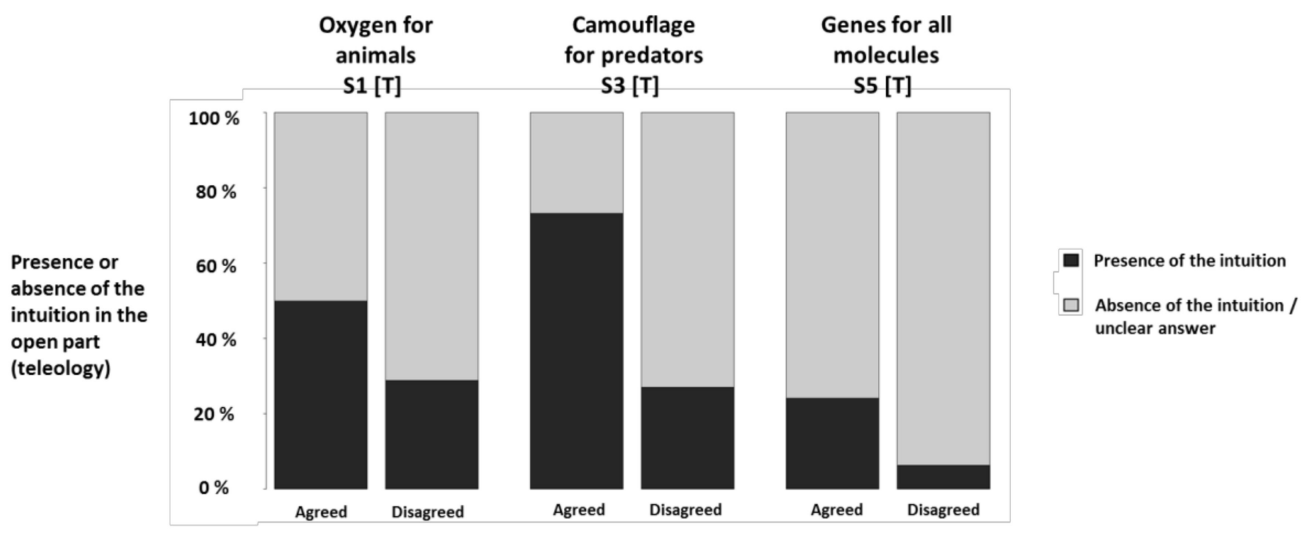

(a) Teleology

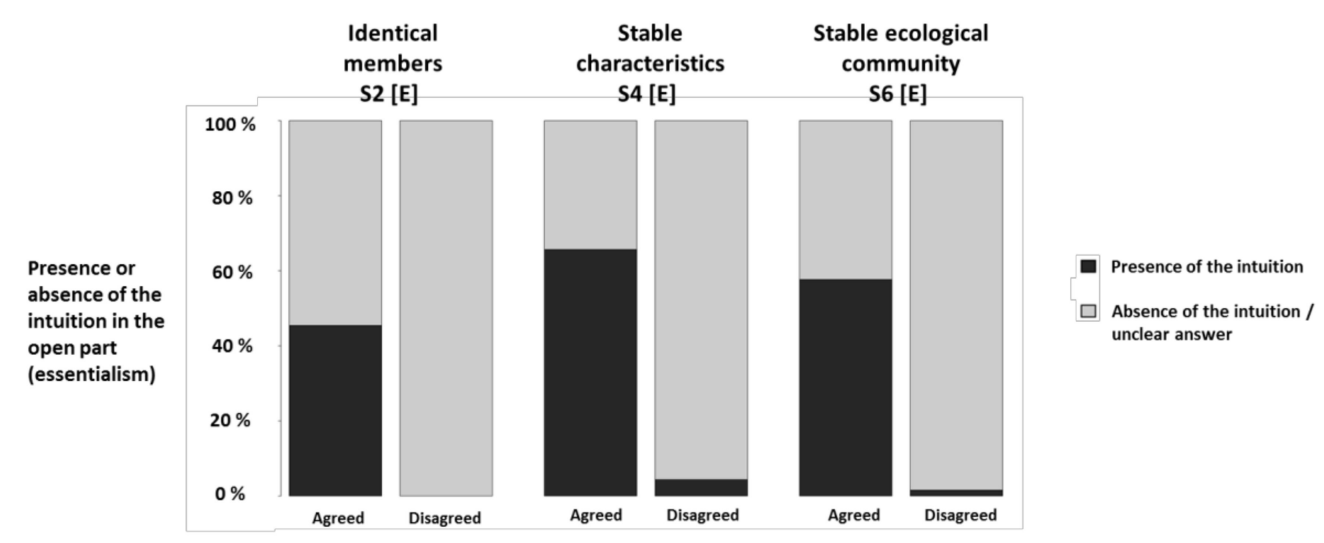

(b) Essentialism

Figure 3. Presence (black) or absence (gray-including unclear answers) of the intuition in the open part, in relation with students' agreement ("agreed") or disagreement ("disagreed") with the respective misconception statement in the closed part. 
It is evident in Figure 3a that those students who expressed an agreement with any of the three misconception statements in the closed parts of the items, also provided a justification in teleological terms more often than those who disagreed with the misconception statements $S_{1}, S_{3}, S_{5}$. However, it is also evident that not all students who agreed with the misconception statements, also provided a respective justification, which suggests that not all of them were consistent. The situation was similar for essentialist statements (Figure $3 b$ ), even though it is evident that students were more consistent in this case, that is among those students who agreed with any of the three misconception statements $\mathrm{S}_{2}, \mathrm{~S}_{4}, \mathrm{~S}_{6}$ also provided a justification in essentialist terms more often than those who disagreed with these statements. Nevertheless, it is clear that very few students among those who disagreed with misconception statements $S_{2}, S_{4}, S_{6}$, provided written responses in essentialist terms (Figure $3 b$ ). This was not the case for teleology.

Table 3 presents the $\mathrm{CW}$ for each participant for the three teleological and the three essentialist statements. The $\mathrm{CW}$ of students answering teleological statements is relatively low: $53 \%$ of students exhibited CW in their answers to two misconception statements and only $14 \%$ to three misconception statements. In contrast, the $\mathrm{CW}$ of students answering essentialist statements was higher as 30\% of students exhibited CW in their answers to two misconception statements and $67 \%$ to three misconception statements. Overall, a rather strong CW is observed as $67 \%$ of the participants were consistent in their responses to the closed and the open part of at least two out of three teleology misconception statements and $97 \%$ of participants were consistent in their responses to the closed and the open part of at least two out of three essentialist misconception statements. However, the responses to all three essentialist statements exhibit considerable $\mathrm{CW}$, with rather strong correlation coefficients, than the one observed in the responses to teleological statements, where two statements exhibit consistency but with weaker correlation coefficients (Table 4).

Table 3. Students' consistency within items for teleology and essentialism.

\begin{tabular}{ccc}
\hline Number of Items & CW in Teleology Items & CW in Rssentialism Ltems \\
\hline $0 / 3$ & $4 \%$ & $1 \%$ \\
$1 / 3$ & $29 \%$ & $2 \%$ \\
$2 / 3$ & $53 \%$ & $30 \%$ \\
$3 / 3$ & $14 \%$ & $67 \%$ \\
\hline
\end{tabular}

Table 4. The consistency within (CW) of each misconception statement. Correlations are based on significant Pearson's Chi-Square tests $\left({ }^{*} 0.05<p<0.10\right.$; ${ }^{* *} 0.001<p<0.05$; ${ }^{* *} p<0.001$ ). Correlation coefficient Phi is also reported, within parentheses.

\begin{tabular}{|c|c|c|c|c|c|c|}
\hline \multirow[b]{2}{*}{$\begin{array}{l}\text { Misconception } \\
\text { Statements }\end{array}$} & \multicolumn{3}{|c|}{ Teleological } & \multicolumn{3}{|c|}{ Essentialist } \\
\hline & $\begin{array}{l}\left(\mathrm{S}_{1}\right) \text { Oxygen } \\
\text { for animals }\end{array}$ & $\begin{array}{l}\left(\mathrm{S}_{3}\right) \text { Camouflage } \\
\text { for predators }\end{array}$ & $\begin{array}{l}\left(\mathrm{S}_{5}\right) \text { Genes for } \\
\text { all molecules }\end{array}$ & $\begin{array}{l}\left(\mathrm{S}_{2}\right) \text { Identical } \\
\text { members }\end{array}$ & $\begin{array}{c}\left(\mathrm{S}_{4}\right) \text { Stable } \\
\text { characteristics }\end{array}$ & $\begin{array}{c}\left(\mathrm{S}_{6}\right) \text { Stable } \\
\text { ecological community }\end{array}$ \\
\hline
\end{tabular}

Given that we explicitly asked students to justify in the open part of each item their choice in the respective closed part, we expected students to be highly consistent. This seems to have been the case for essentialism where $97 \%$ of them were consistent to at least 2 out of 3 items, but not for teleology where this was the case for only $67 \%$ of them. This is an interesting finding for teleology. As is evident in Figure 3a above, about one in three students who disagreed with the teleological misconception statements $\left(S_{1}, S_{3}, S_{5}\right)$ eventually exhibited the misconception in their justifications (about $29 \%$ for $S_{1}$ and about $27 \%$ for $S_{3}$, but only $6 \%$ for $S_{5}$ ). This might indicate that whereas students may initially seem to express a disagreement with a teleological misconception, they may actually hold it and only express it when they are asked to provide a written justification and therefore express 
their own thoughts. This is why 2-tier tests like the one used in this study might provide more detailed information about students' misconceptions.

Therefore, with respect to our second research question, that is whether first year undergraduate biology students were consistent in their responses within the various items, we can conclude that students were overall more consistent in their responses to the essentialism items than the teleology items. This lower consistency in the case of teleology items is interesting and could be due to the fact that there was not enough information to discriminate between selective or discriminate teleology, but also that students are unaware of a misconception that they hold. This is something that should be investigated further in future studies.

\subsection{Students' Consistency between Items}

Consistency between items (CB) is a measure of the relationship among students' written responses to the open parts of items that relate to the same type of misconception. In other words, it is a measure of whether a student provided teleological justifications to all three "teleology" items or essentialist justifications to all three "essentialism" items. This allows us to look into whether the intuition is simultaneously found or simultaneously rejected by students across the different related misconception statements $\left(\mathrm{S}_{1}, \mathrm{~S}_{3}, \mathrm{~S}_{5}\right.$ for teleology and $\mathrm{S}_{2}, \mathrm{~S}_{4}, \mathrm{~S}_{6}$ for essentialism). As is evident in Table 5, there were no significant correlations between answers to any two teleological statements, neither in the closed nor in the open part. As also shown in Table 6, there were no correlations between agreements to two different essentialist statements, neither in the closed nor in the open parts. In both cases, there were only two significant correlations between answers to two different misconception statements, one between the answers to the closed and one between the answers to the open parts, but their strength is relatively low, as shown by the moderately low p-values and phi coefficients.

Table 5. Correlations between students' answers across the open parts and the closed parts of teleological misconception statements. Correlations are based on significant Pearson's Chi-Square tests $\left({ }^{*} 0.05<p<0.10\right.$; no correlation: $\left.p>0.10\right)$. Correlation coefficient $\mathrm{Phi}$ is also reported, within parentheses.

\begin{tabular}{ccc}
\hline & CB for Teleology Items & $\begin{array}{c}\text { Significance of Correlation } \\
\text { (Correlation Coefficient) }\end{array}$ \\
\hline \multirow{3}{*}{$\begin{array}{c}\text { Comparisons of closed } \\
\text { parts of items }\end{array}$} & $\left(\mathrm{S}_{1}\right)$ Oxygen for animals $/\left(\mathrm{S}_{3}\right)$ & no correlation \\
Camouflage for predators & $0.12)$ \\
\cline { 2 - 3 } & $\left(\mathrm{S}_{1}\right)$ Oxygen for animals $/\left(\mathrm{S}_{5}\right)$ & $\begin{array}{c}\text { no correlation } \\
\text { Genes for all molecules }\end{array}$ \\
\cline { 2 - 3 } & $\left(\mathrm{S}_{3}\right)$ Camouflage for predators $/\left(\mathrm{S}_{5}\right)$ & $(0.12)$ \\
Genes for all molecules & $*$ \\
Comparisons of open & $\left(\mathrm{S}_{1}\right)$ Oxygen for animals $/\left(\mathrm{S}_{3}\right)$ & $(0.21)$ \\
\hline parts of items & Camouflage for predators & no correlation \\
& $\left(\mathrm{S}_{1}\right)$ Oxygen for animals $/\left(\mathrm{S}_{5}\right)$ & $(0.14)$ \\
\cline { 2 - 3 } & Genes for all molecules & no correlation \\
& $\left(\mathrm{S}_{3}\right)$ Camouflage for predators $/\left(\mathrm{S}_{5}\right)$ & $(-0.14)$ \\
\hline
\end{tabular}


Table 6. Correlations between students' answers across the open parts and the closed parts of essentialist misconception statements. Correlations are based on significant Pearson's Chi-Square tests $\left({ }^{*} 0.05<p<0.10\right.$; no correlation: $\left.p>0.10\right)$. Correlation coefficient Phi is also reported, within parentheses.

\begin{tabular}{ccc}
\hline & CB for Essentialism Items & $\begin{array}{c}\text { Significance of Correlation } \\
\text { (Correlation Coefficient) }\end{array}$ \\
\hline \multirow{3}{*}{$\begin{array}{c}\text { Comparisons of closed } \\
\text { parts of items }\end{array}$} & $\left(\mathrm{S}_{2}\right)$ Identical members $/\left(\mathrm{S}_{4}\right)$ Stable & no correlation \\
characteristics & $(0.13)$ \\
\cline { 2 - 3 } & $\left(\mathrm{S}_{2}\right)$ Identical members $/\left(\mathrm{S}_{6}\right)$ Stable & $*$ \\
& ecological community & $(0.22)$ \\
\cline { 2 - 3 } & $\left(\mathrm{S}_{4}\right)$ Stable characteristics $/\left(\mathrm{S}_{6}\right)$ & no correlation \\
& Stable ecological community & $(-0.03)$ \\
\hline $\begin{array}{c}\text { Comparisons of open } \\
\text { parts of items }\end{array}$ & $\left(\mathrm{S}_{2}\right)$ Identical members $/\left(\mathrm{S}_{4}\right)$ Stable & no correlation \\
& characteristics & $(0.14)$ \\
\cline { 2 - 3 } & $\left(\mathrm{S}_{2}\right)$ Identical members $/\left(\mathrm{S}_{6}\right)$ Stable & no correlation \\
& ecological community & $(0.02)$ \\
\cline { 2 - 3 } & $\left(\mathrm{S}_{4}\right)$ Stable characteristics $/\left(\mathrm{S}_{6}\right)$ & $*$ \\
Stable ecological community & $(0.22)$ \\
\hline
\end{tabular}

Overall, this low consistency between items of the same type indicates that the features of the different items likely had an effect on students' responses, as they expressed a different level of agreement or disagreement with misconception statements that were otherwise based on the same underlying idea. This may be related either to students' familiarity with the context of each item, or with how intuitive they found each idea.

\subsection{Overall Relation between Teleological and Essentialist Conceptions}

In order to produce an overall view of students' teleological and essentialist conceptions, we calculated a score for each student based on his/her choices to the open parts of the various items ( 1 point for a complete agreement, 2 points for a partial agreement, 3 points for a partial disagreement, 4 points for a complete disagreement). Based on these scores, each student was assigned a position on the map in Figure 4. This two-dimensional map describing the positions of the students shows no evidence of correlation between essentialist and teleological thinking, with regard to our research question 4 (Is there a correlation between 1st year undergraduate biology students' teleological and essentialist conceptions as documented by their responses to the questions of this study?). For example, the student designated by number 57 (top-right corner) generally disagreed with both the teleological and the essentialist misconception statements; the student designated by number 22 (down-right corner) generally disagreed with the teleological misconception statements but agreed with the essentialist ones; the student designated by number 61 (top-left corner) mostly disagreed with the essentialist misconception statements but agreed with the teleological ones. The distribution of students across this map indicates that overall students held all possible combinations of conceptions, indicating that there is no clear correlation between teleological and essentialist thinking (Pearson correlation test non-significant, $p=0.8$ ). 


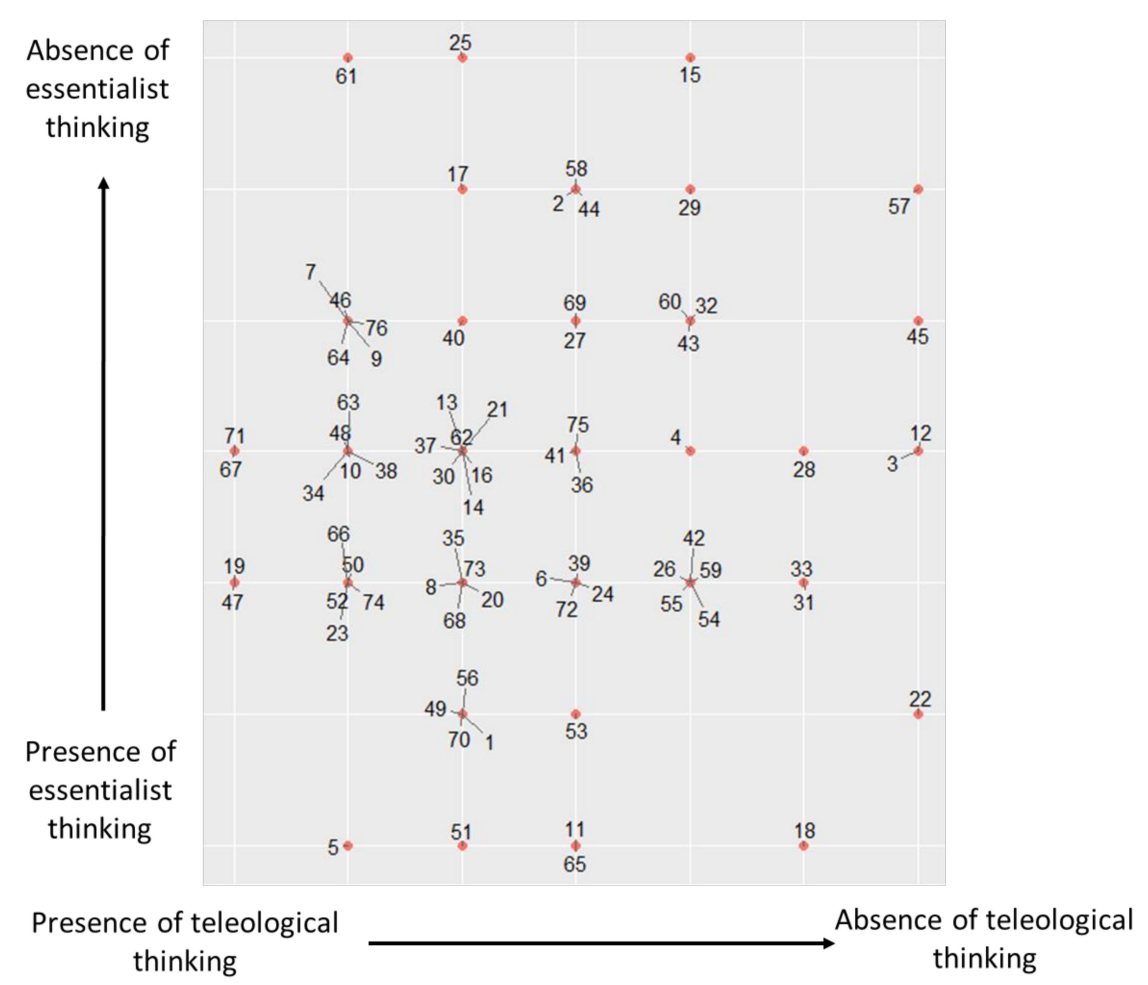

Figure 4. Map of students. Each number represents the position of a student, depending on both his/her inferred teleological thinking and his/her inferred essentialist thinking.

Furthermore, according to the regression analyses (Table 7), the students who agreed more with teleological misconception statements also exhibited more teleological reasoning in their written justifications to all teleological misconception statements; however, agreeing with teleological misconception statements was not associated with the presence of essentialist intuitions in the respective written justifications. Similarly, the students who agreed more with essentialist misconception statements also exhibited more essentialist reasoning in their written justifications to all essentialist misconception statements; but agreeing with essentialist misconception statements was unrelated with the presence of teleological intuitions in the respective written justifications. These results overall indicate that there was no correlation between students' teleological and essentialist conceptions.

Table 7. Relations between agreement with biological misconception statements (closed part) and presence of intuitions in written explanations (open part).

\begin{tabular}{cccc}
\hline \multicolumn{4}{c}{$\begin{array}{c}\text { Open Part } \\
\text { Frequency of Intuitions in Explanations }\end{array}$} \\
( $\beta$ are Standardized Regression Coefficients, with Standardized Errors in Brackets)
\end{tabular}




\section{Discussions}

In this study we aimed to investigate whether there was any correlation between biology undergraduate students' responses related to teleology and essentialism. We found the respective misconceptions to be quite prevalent among the participating students (research question 1), with $97 \%$ of participants agreeing with at least one misconception statement. In addition, we found that students were consistent within items, that is that they exhibited the same conception between their responses in the closed and the open part of the same item (research question 2). However, there were differences in students' consistency within the various items. We also found that students were rather inconsistent across items, that is that most students would not agree with all teleological or all essentialist misconception statements, but only with some of them (research question 3). However, there were important differences across the various items. Finally, even though at the conceptual level teleology and essentialism relate to intentionality, like the Coley \& Tanner study [18] we found no correlation between students' teleological and essentialist conceptions (research question 4) as is most evident in Figure 4.

\subsection{Comparison of Results to Those in the Coley \& Tanner Study}

Given the explicit connection of our study to the one reported in Coley and Tanner [18], it is interesting to compare the findings and conclusions of the two studies in more detail (for simplicity, we hereafter refer to that study simply as CT study). A first main difference is that whereas the CT study involved both biology majors and non-biology majors, our study only involved undergraduate biology students. However, as we administered the questionnaire on the first day of the first semester, the participants in our study held the conceptions that they developed while at school and there is no possible effect of their university studies in biology, which at that point had not practically started yet. We acknowledge that there might be some differences between the participants in our study and students from other (not related to biology) departments from the same university because of the different amount of biology courses that they attended at high school. Nevertheless, any such differences would be unrelated to the ones that one would expect to find by comparing biology undergraduates and students in other disciplines that would be due to their university studies. However, below we compare the findings for the biology undergraduates who participated in our study and only the biology majors in the CT study. Overall, $97 \%$ of participants in our study agreed with at least one misconception statement, whereas this was the case for $93 \%$ of biology majors in the CT study.

Let us first look at the level of students' agreement with the misconception statements in the two studies (Figure 1 above and Figures 2 and 3, in the CT study). The teleological statement $\mathrm{S}_{1}$ "Oxygen for animals" was endorsed by more students in our study (37\%) than in the CT one (20\%), whereas the teleological statement $\mathrm{S}_{3}$ "Camouflage for predators" was endorsed by more students in the CT study $(80 \%)$ compared to the present one $(60 \%)$. In sum, agreements with teleological statements may slightly differ between the two studies, however statement $\mathrm{S}_{1}$ "Oxygen for animals" was endorsed by relatively few students whereas statement $S_{3}$ "Camouflage for predators" was endorsed by relatively many students in both studies. Regarding essentialism, statement $\mathrm{S}_{2}$ "Identical members" was endorsed by nearly $10 \%$ of students in both studies, whereas statement $\mathrm{S}_{6}$ "Stable ecological community" was endorsed by relatively less students in our study (27\%) than in the CT one (35\%). Therefore, and overall, there exist slight differences in students' agreement or disagreement with the essentialist statements in the CT study and the present one. We should also note that the wording of the teleology statement $\mathrm{S}_{5}$ "Genes for all molecules" and the essentialist statement $\mathrm{S}_{4}$ "Stable characteristics" in our study were very different from the other statements used in the CT study; therefore, comparing them seems irrelevant, and this holds for the other comparisons mentioned in this article.

Besides these results, it is also interesting to look into students' written justifications (Figures 2 and 3a,b and Figures 8 and 9 in [18]). The number of students who agreed with the misconception statement S1 "Oxygen for animals" and also provided a written justification in 
teleological terms was higher in our study than the CT one. In particular, among those who agreed with $S_{1}$, those who also provided a teleological justification were $50 \%$ in our study and $23 \%$ in the CT study; among those who disagreed with $\mathrm{S}_{1}$, those who also provided a teleological justification were $28 \%$ in our study versus $5 \%$ in the CT study. Similarly, the number of students who agreed with the misconception statement $\mathrm{S}_{3}$ "Camouflage for predators" and also provided a written justification in teleological terms was higher in our study than the CT one. In particular, among those who agreed with $\mathrm{S}_{3}$, those who also provided a teleological justification were $73 \%$ in our study and $52 \%$ in the CT study; among those who disagreed with $\mathrm{S}_{3}$, those who also provided a teleological justification were $27 \%$ in our study and nobody in the CT study. Differences notwithstanding, there are also some similar conclusions from both studies: first, those participants who agreed with the teleological misconception statements are more likely to justify them in teleological terms than those who disagreed with them; second the presence of teleological thinking among those agreeing with $S_{3}$ is found in both studies to be stronger than the presence of teleological thinking among those agreeing with $S_{1}$.

Turning to essentialism, the number of students who agreed with the misconception statement $\mathrm{S}_{2}$ "Identical members" and also provided a written justification in essentialist terms was higher in the CT study than the present one. In particular, among those who agreed with $S_{2}$, those who also provided an essentialist justification were $62 \%$ in the CT study and $45 \%$ in our study; among those who disagreed with $\mathrm{S}_{2}$, those who also provided an essentialist justification were $4 \%$ in the CT study and nobody in our study. In contrast, the number of students who agreed with the misconception statement $\mathrm{S}_{6}$ "Stable ecological community" and also provided a written justification in essentialist terms was higher in our study than the CT one. In particular, among those who agreed with $S_{6}$, those who also provided an essentialist justification were $58 \%$ in our study and $48 \%$ in the CT study; among those who disagreed with $\mathrm{S}_{6}$, those who also provided an essentialist justification were $1 \%$ in our study and $5 \%$ in the CT study. Again, and even though numbers may slightly differ, two general conclusions can be drawn from both studies: first, participants who agreed with statement $S_{2}$ are more likely to justify it in essentialist terms than those who disagreed with it; second the presence of essentialist thinking among those agreeing with S6 was found in both studies to be a bit stronger than the presence of essentialist thinking among those agreeing with $S_{2}$, while the presence of essentialist thinking among those disagreeing with $S_{2}$ and $S_{6}$ was found very low in our study.

It is also interesting to compare students' consistency between the closed and the open part of each item (what we have called "consistency within", or CW, in this article) (see Table 4 above and Table 3 in the CT study). Similarly to the CT study, the correlation between the closed and the open part of teleological statement $\mathrm{S}_{3}$ "Camouflage for predators" was also found significant in our study. However, the correlation for the statement $S_{1}$ "Oxygen for animals" was significant in our study, while it was not significant in the CT study. Regarding essentialism, for both statements $\mathrm{S}_{2}$ "Identical members" and $\mathrm{S}_{6}$ "Stable ecological community" there was a correlation between students' responses to the open and closed parts in both studies. Overall, concerning students' consistency within items, the findings in the present study and the CT study are in agreement for the three out of four compared misconception statements, with students overall exhibiting consistency in their responses to the closed and the open part of each item.

The results of the regression analysis in our study (Table 6) and that in the CT study (Table 4) are overall in agreement. First, in both studies, the agreement with teleological misconception statements was positively associated with the presence of a teleological intuition, but not with that of an essentialist one, in the written justifications. Also, in both studies, a positive association was found between the agreement with essentialist misconception statements and the presence of an essentialist, but not a teleological intuition, in the written justifications. Second, comparing the coefficients of the regression: (a) the strength of the association between the agreement with the teleological statements and the presence of this intuition in the justification part was slightly higher in our study $(0.38)$ than the CT one (0.31); (b) the strength of the association between the agreement with the essentialist statements and the presence of this intuition in the justification part was much higher in our study (0.63) than in 
the CT one (0.32). An explanation for this difference is that our regression analysis was computed with two predictors "teleological thinking" and "essentialist thinking", whereas in the ones in the CT study used these two plus "anthropocentric thinking"; as a result, the coefficients are higher in our case.

\subsection{Limitations of the Present Study}

The small sample size and the misconception statements used pose limitations to the conclusions that one can draw from this study. Nevertheless, as the relation between teleological and essentialist views is a relatively underexplored area, we consider our results as a useful indication of what is happening. Further research is of course required with larger samples and questionnaires that would support more detailed inferences about students' views. However, as our results and those of the Coley and Tanner study [18] overall point to a lack of correlation between teleological and essentialist conceptions, we think that this work is on the right track. Another potential limitation stems from the fact that in the coding we did not distinguish between the (scientifically legitimate) selective teleology and the (scientifically illegitimate) design teleology (see [21]), as the short length of students' responses did not allow for such a distinction to be made. For the same reasons, we did not analyze is detail what students could perceive as the essences of organisms (their genes? their developmental potential?). These distinctions are very important however it was impossible to reliably make them based on our data. Further studies, possibly based on interviews that would delve deeper into students' thinking, would be required for this purpose.

\subsection{Conclusions from the Present Study and Implications for Undergraduate Biology Education}

Overall, our findings point to some interesting conclusions. The first is that with the exception of one question to which many students provided unclear responses $\left(S_{5}\right)$, in most other cases there was generally a consistency between a student's choice in the closed part and their justification in the open part of the same item. This is important to note for the reliability of our findings as in the majority of cases the response in the open part of the item stands as a confirmation that students understood what was asked in the closed part. A second important finding is that there is a variety of combinations of views held by students and thus no clear correlation between their responses, and therefore of their teleological and essentialist conceptions.

The most important implications from these findings are that undergraduate students' teleological and essentialist conceptions must be explicitly addressed during undergraduate biology instruction, separately from each other. This means that while teaching biology content, attention should be paid not only to refrain from enhancing students' teleological and essentialist conceptions, but also to explicitly address them and explain why they are problematic. At the same time, as teleology and essentialism are conceptually distinct, despite their common reliance on intentionality, and the respective conceptions that students hold are also non-correlated, each of these should be separately addressed.

Overall, our teleological and essentialist intuitions produce the following misconception: organisms of a particular kind/category have particular fixed characters for some intended use. This is certainly true for artifacts, but not for organisms. Artifacts have several parts appropriately designed for their intended use, which in turn is their essence. But students should learn to refrain from extending this reasoning to nature, consciously or unconsciously thinking about the parts of organisms as if they had specific intended uses. We can definitely say that an airplane has wings in order to fly; despite the differences among airplanes, they are all designed in order to fly and this constitutes part of their essence. But we cannot similarly state that a bird has wings in order to fly. In contrast, we should say that some birds fly because they have wings (among other properties). There are two main differences between birds and airplanes: birds are not designed for a purpose, and the variation among them is much higher than among airplanes - to the extent that some birds do not fly, like penguins and ostriches. These are points that must be explicitly discussed during undergraduate biology teaching, which must move away from being simply a means of transmission of content knowledge. 
As no correlation was found between teleological and essentialist conceptions, one might suggest that these misconceptions must be addressed independently from one another during teaching. Let us consider another example in order to suggest a simple way in which this could be done. Imagine the comparison of sharks and dolphins in terms of two of their features: their shapes and their way of breathing. A simple way to explicitly address essentialism is to make the comparison between "dolphins" and "sharks" in plural, and not between "the dolphin" and "the shark". In this way, reference is made to populations (i.e., dolphins, sharks-plural) and not to individuals (i.e., dolphin, shark-singular). This way of referring to populations entails that there are many different individuals. Then teachers might explicitly refer to the fact that individuals within a population are not identical, and exhibit an enormous phenotypic and genetic variation. This is the basis for evolutionary change, as under different conditions a population that has variation can evolve to different directions. This is one way in which essentialist misconceptions could be addressed.

Then, one could focus on teleological misconceptions. If one asked why dolphins and sharks have hydrodynamic shapes, one might answer that they have such shapes in order to be able to swim fast underwater. Dolphins and sharks are relatively large marine organisms, which are predators, and face similar challenges in the environment in which they live, where they need to be able to catch prey in order to survive. However, at the same time one might wonder why it is only sharks that have gills that allow them to breathe underwater, whereas dolphins have lungs and thus need to periodically get out of the water in order to breathe. In this case, one might claim that sharks have gills in order to breathe underwater, but such a claim cannot be made for dolphins. Organisms do not have all the optimal features for their survival. In some cases, the same "solutions" evolve to address the same "problem", as is the case of their shape; in other cases, such as their respiratory system, this not the case. Therefore, teleological misconceptions can be addressed by emphasizing that some, but not all, features may exist for a purpose, which is the outcome of evolution and not design. Some features may simply exist as byproducts of evolution [42].

Indeed, it has been found that activities especially developed to address students' misconceptions about purpose and design in nature and bring them in conceptual conflict situations can have an important effect in promoting conceptual change in evolution. The activity presented in [43] is a simple pencil-paper activity that guides students to realize that mutations producing intra-specific variation and unpredictable events resulting in differential survival depending on the environment are two important components of the evolutionary process. The results showed that the activity guided students to combine their previous knowledge and build their own understanding of how evolution proceeds. Students who were interviewed a year after the intervention and provided evolutionary explanations to all tasks considered mutations and the teaching about the role of unpredictability in evolution as the major factors that made them reject their preconceptions and replace their intuitive explanations with evolutionary ones. The activity, in particular, some of them noted, had a crucial role in making them reconsider their initial teleological conceptions [38].

The main conclusion from our results is that teleological and essentialist misconceptions may persist after secondary biology teaching. Therefore, teaching about evolution could be more effective if students' misconceptions were explicitly discussed and challenged during biology classes. This should be done in a variety of ways and contexts because, as our findings show, these misconceptions may or may not be expressed. But if this is achieved, and if students are brought to a conceptual conflict situation in which they will realize that their intuitive responses do not work and see them challenged, then a better understanding of evolution, and of biology more broadly, could be possible.

Author Contributions: K.K. and C.H. conceived the study; K.K., C.H., and P.S. collected the data; K. K., P.S., F. S., and A.M. analyzed the data; K.K. and F.S. wrote the article; all authors read and approved the final article.

Acknowledgments: F.S. and K.K. acknowledge the support of the Swiss National Science Foundation while working on the research presented in this article (project number: 100019_162679).

Conflicts of Interest: The authors declare no conflict of interest. 


\section{Appendix A The Items Used in the Study Reported in This Article (in French)}

Répondez au meilleur de votre connaissance et expliquez votre réponse en quelques mots.

1. Les plantes produisent de l'oxygène pour que les animaux puissent respirer.

$\square \quad$ je suis en désaccord

$\square \quad$ je suis plutôt en désaccord

$\square \quad$ je suis plutôt d'accord

$\square \quad$ je suis complètement d'accord

$\square \quad$ je ne sais pas

Expliquez votre réponse:

2. A part les différences dues à l'âge et au sexe, les membres d'une même espèce sont identiques.

$\square \quad$ je suis en désaccord

$\square \quad$ je suis plutôt en désaccord

$\square \quad$ je suis plutôt d'accord

$\square \quad$ je suis complètement d'accord

$\square$ je ne sais pas

Expliquez votre réponse:

3. Les animaux développent du camouflage protecteur pour éviter leurs prédateurs.

$\square \quad$ je suis en désaccord

$\square \quad$ je suis plutôt en désaccord

$\square \quad$ je suis plutôt d'accord

$\square \quad$ je suis complètement d'accord

$\square \quad$ je ne sais pas

Expliquez votre réponse:

4. Les espèces peuvent changer pendant l'évolution, mais certaines caractéristiques restent toujours les mêmes.

$\square \quad$ je suis en désaccord

$\square \quad$ je suis plutôt en désaccord

$\square \quad$ je suis plutôt d'accord

$\square \quad$ je suis complètement d'accord

$\square \quad$ je ne sais pas

Expliquez votre réponse:

5. Les organismes ont des gènes pour produire toutes les molécules dont ils ont besoin.

$\square$ je suis en désaccord

$\square \quad$ je suis plutôt en désaccord

$\square \quad$ je suis plutôt d'accord

$\square \quad$ je suis complètement d'accord

$\square \quad$ je ne sais pas

Expliquez votre réponse: 
6. Sans influences extérieures, une communauté écologique restera stable indéfiniment.

$\square \quad$ je suis en désaccord

$\square \quad$ je suis plutôt en désaccord

$\square \quad$ je suis plutôt d'accord

$\square \quad$ je suis complètement d'accord

$\square \quad$ je ne sais pas

Expliquez votre réponse:

\section{Appendix B The Items Used in the Study Reported in This Article (in English)}

Reply to the best of your knowledge and explain your reply in a few words.

1. Plants produce oxygen in order for the animals to be able to do respiration.
I completely disagree
$\square \quad$ I mostly disagree
$\square \quad$ I mostly agree
$\square \quad$ I completely agree
$\square \quad$ I do not know

Explain your response:

2. Except for the differences related to age and sex, the members of the same species are identical.
I completely disagree
$\square \quad$ I mostly disagree
$\square \quad$ I mostly agree
$\square \quad$ I completely agree
$\square \quad$ I do not know

Explain your response:

3. Animals develop protective concealment in order to avoid their predators.
I completely disagree
$\square \quad$ I mostly disagree
$\square \quad$ I mostly agree
$\square \quad$ I completely agree
$\square \quad$ I do not know

Explain your response:

4. Species can change in the course of evolution, but certain features always remain the same.
$\square \quad$ I completely disagree
$\square \quad$ I mostly disagree
$\square \quad$ I mostly agree
$\square \quad$ I completely agree
$\square \quad$ I do not know

Explain your response: 
5. Organisms have genes in order to produce all the molecules that they need.

I completely disagree

I mostly disagree

I mostly agree

I completely agree

I do not know

Explain your response:

6. Without external influences, an ecological community will remain stable indefinitely.

I completely disagree

I mostly disagree

I mostly agree

I completely agree

I do not know

Explain your response:

\section{References}

1. Vosniadou, S. Reframing the classical approach to conceptual change: Preconceptions, misconceptions and synthetic models. In Second International Handbook of Science Education; Fraser, B.J., Tobin, K., McRobbie, C.J., Eds.; Springer: Dordrecht, The Netherlands, 2012; pp. 119-130. ISBN 978-1-4020-9041-7.

2. Leonard, M.J.; Kalinowski, S.T.; Andrews, T.C. Misconceptions yesterday, today, and tomorrow. CBE Life Sci. Educ. 2014, 13, 179-186. [CrossRef] [PubMed]

3. Keil, F.C. Science starts early. Science 2011, 331, 1022-1023. [CrossRef] [PubMed]

4. Solomon, G.E.; Johnson, S.C.; Zaitchik, D.; Carey, S. Like father, like son: Young children's understanding of how and why offspring resemble their parents. Child. Dev. 1996, 67, 151-171. [CrossRef] [PubMed]

5. Williams, J.M.; Smith, L.A. Concepts of kinship relations and inheritance in childhood and adolescence. Br. J. Dev. Psychol. 2010, 28, 523-546. [CrossRef] [PubMed]

6. Williams, J.M. Children and adolescents' understandings of family resemblance: A study of naïve inheritance concepts. Br. J. Dev. Psychol. 2012, 30, 225-252. [CrossRef] [PubMed]

7. Banet, E.; Ayuso, E. Teaching genetics at secondary school: A strategy for teaching about the location of inheritance information. Sci. Educ. 2000, 84, 313-351. [CrossRef]

8. Castéra, J.; Clément, P. Teachers' conceptions about the genetic determinism of human behaviour: A survey in 23 countries. Sci. Educ. 2014, 23, 417-443. [CrossRef]

9. Gericke, N.M.; Hagberg, M.; dos Santos, V.C.; Joaquim, L.M.; El-Hani, C.N. Conceptual variation or incoherence? Textbook discourse on genes in six countries. Sci. Educ. 2014, 23, 381. [CrossRef]

10. Stern, F.; Kampourakis, K. Teaching for genetics literacy in the post-genomic era. Stud. Sci. Educ. 2017, 53, 193-225. [CrossRef]

11. Andrews, T.M.; Price, R.M.; Mead, L.S.; McElhinny, T.L.; Thanukos, A.; Perez, K.E.; Herreid, C.F.; Terry, D.R.; Lemons, P.P. Biology Undergraduates' Misconceptions about genetic drift. CBE Life Sci. Educ. 2012, 11, 248-259. [CrossRef] [PubMed]

12. Anderson, D.L.; Fisher, K.M.; Norman, G.J. Development and evaluation of the conceptual inventory of natural selection. J. Res. Sci. Teach. 2002, 39, 952-978. [CrossRef]

13. Wilson, C.D.; Anderson, C.W.; Heidemann, M.; Merrill, J.E.; Merritt, B.W.; Richmond, G.; Sibley, D.F.; Parker, J.M. Assessing students' ability to trace matter in dynamic systems in Cell Biology. CBE Life Sci. Educ. 2006, 5, 323-331. [CrossRef] [PubMed]

14. Canal, P. Photosynthesis and "inverse respiration" in plants: an inevitable misconception? Int. J. Sc. Educ. 1999, 21, 363-371. [CrossRef] 
15. Kelemen, D. Teleological minds: How natural intuitions about agency and purpose influence learning about evolution. In Evolution Challenges: Integrating Research and Practice in Teaching and Learning about Evolution; Rosengren, K.S., Brem, S., Evans, E.M., Sinatra, G., Eds.; Oxford University Press: New York, NY, USA, 2012; pp. 66-92. ISBN 978-0-19-994955-7.

16. Gelman, S.A.; Rhodes, M. "Two-thousand years of stasis": How psychological essentialism impedes evolutionary understanding. In Evolution Challenges: Integrating Research and Practice in Teaching and Learning about Evolution; Rosengren, K.S., Brem, S., Evans, E.M., Sinatra, G., Eds.; Oxford University Press: New York, NY, USA, 2012; ISBN 978-0-19-994955-7.

17. Kampourakis, K. Understanding Evolution, 1st ed.; Cambridge University Press: New York, NY, USA, 2014; ISBN 978-1-107-61020-0.

18. Coley, J.D.; Tanner, K.D. Relations between intuitive biological thinking and biological misconceptions in Biology majors and nonmajors. CBE Life Sci. Educ. 2015, 14. [CrossRef] [PubMed]

19. Coley, J.D.; Tanner, K.D. Common origins of diverse misconceptions: Cognitive principles and the development of Biology thinking. CBE Life Sci. Educ. 2012, 11, 209-215. [CrossRef] [PubMed]

20. Tamir, P.; Zohar, A. Anthropomorphism and teleology in reasoning about biological phenomena. Sci. Educ. 1991, 75, 57-67. [CrossRef]

21. Lennox, J.G.; Kampourakis, K. Biological teleology: The need for history. In The Philosophy of Biology: A Companion for Educators; Kampourakis, K., Ed.; Springer: Dordrecht, The Netherlands, 2013; pp. 421-454.

22. Kelemen, D. Why are rocks pointy? Children's preference for teleological explanations of the natural world. Dev. Psychol. 1999, 35, 1440-1452. [CrossRef] [PubMed]

23. Kelemen, D. Function, goals and intention: Children's teleological reasoning about objects. Trends Cogn. Sci. 1999, 3, 461-468. [CrossRef]

24. Keil, F.C. The birth and nurturance of concepts by domains: The origins of concepts of living things. In Mapping the Mind: Domain Specificity in Cognition and Culture; Hirschfeld, L.A., Gelman, S.A., Eds.; Cambridge University Press.: Cambridge, UK, 1994; pp. 234-254.

25. Kampourakis, K.; Palaiokrassa, E.; Papadopoulou, M.; Pavlidi, V.; Argyropoulou, M. Children's intuitive teleology: Shifting the focus of evolution education research. Evo. Educ. Outreach 2012, 5, 279-291. [CrossRef]

26. Ware, E.A.; Gelman, S.A. You get what you need: An examination of purpose-based inheritance reasoning in undergraduates, preschoolers, and biological experts. Cogn. Science 2014, 38, 197-243. [CrossRef]

27. Kelemen, D.; Rottman, J.; Seston, R. Professional physical scientists display tenacious teleological tendencies: Purpose-based reasoning as a cognitive default. J Exp. Psychol. Gen. 2013, 142, 1074-1083. [CrossRef] [PubMed]

28. Casler, K.; Kelemen, D. Developmental continuity in teleo-functional explanation: Reasoning about nature among romanian romani adults. J. Cogn. Dev. 2008, 9, 340-362. [CrossRef]

29. Rottman, J.; Zhu, L.; Wang, W.; Schillaci, R.S.; Clark, K.J.; Kelemen, D. Cultural influences on the teleological stance: Evidence from China. Relig. Brain Beha. 2017, 7, 17-26. [CrossRef]

30. Wilkins, J. Essentialism in Biology. In The Philosophy of Biology: A Companion for Educators; Kampourakis, K., Ed.; Springer: Dordrecht, The Netherlands, 2013; pp. 395-420.

31. Gelman, S.A. The Essential Child: Origins of Essentialism in Everyday Thought; Oxford University Press: New York, NY, USA, 2003; ISBN 978-0-19-515406-1.

32. Walsh, D. Evolutionary essentialism. Br. J. Philos. Sci. 2006, 57, 425-448. [CrossRef]

33. Bateson, P.; Glucksmann, P. Plasticity Robustness Development and Evolution; Cambridge University Press: Cambridge, UK, 2011; ISBN 978-0-521-73620-6.

34. Bloom, P. Descartes' Baby: How the Science of Child Development Explains What Makes Us Human; Basic Books: New York, NY, USA, 2004; ISBN 978-0-465-00786-8.

35. Gelman, S.A.; Wellman, H.M. Insides and essences: Early understandings of the non-obvious. Cognition 1991, 38, 213-244. [CrossRef]

36. Shtulman, A.; Schulz, L. The relation between essentialist beliefs and evolutionary reasoning. Cogn. Sci. 2008, 32, 1049-1062. [CrossRef] [PubMed]

37. Gelman, S.A. Essentialism in everyday thought. Psychol. Sci. Agenda 2005, 19, 1-6.

38. Kampourakis, K.; Zogza, V. Preliminary evolutionary explanations: A basic framework for conceptual change and explanatory coherence in evolution. Sci. Educ. 2009, 18, 1313-1340. [CrossRef] 
39. Nehm, R.H.; Ha, M. Item feature effects in evolution assessment. J. Res Sci. Teach. 2011, 48, $237-256$. [CrossRef]

40. Tsui, C.-Y.; Treagust, D. Evaluating secondary students' scientific reasoning in genetics using a two-tier diagnostic instrument. Int. J. Sci. Educ. 2010, 32, 1073-1098. [CrossRef]

41. Field, A.; Miles, J.; Field, Z. Discovering Statistics Using R; SAGE Publications Ltd: London, UK, 2012; ISBN 978-1-4462-0046-9.

42. Gould, S.J.; Lewontin, R.C. The spandrels of San Marco and the Panglossian paradigm: A critique of the adaptationist programme. Proc. R. Soc. Lond. B. 1979, 205, 581-598. [CrossRef] [PubMed]

43. Kampourakis, K. The Finches' beaks: Introducing evolutionary concepts. Sci. Scope 2006, 29, 14-17.

C 2018 by the authors. Licensee MDPI, Basel, Switzerland. This article is an open access article distributed under the terms and conditions of the Creative Commons Attribution (CC BY) license (http://creativecommons.org/licenses/by/4.0/). 